\title{
A Comparison Of The Market Orientation Of Chinese And US Firms
}

Darlene Brannigan Smith, (E-mail: dsmith@ubalt.edu), University of Baltimore Dennis A. Pitta, (E-mail: dsmith@ubalt.edu), University of Baltimore Lee Richardson, (E-mail: dsmith@ubalt.edu), University of Baltimore

\begin{abstract}
A lack of empirical research exists on marketing orientation in China. In order to begin to address this research gap, a study was conducted assessing managers' perceptions of the market orientation of Chinese firms and its impact on business performance. Multiple measures of market orientation and business performance were assessed and analysis was conducted across different types of organizations and in different industries. This analysis shows that Chinese firms have a strong market orientation. They recognize the importance of being kept informed about environmental trends, competitor activities and the evolving needs of their customers. They disseminate information among their staff and respond to opportunities to provide better products and quality services to their customers. Although the relationship between market orientation and business performance may be complex, this study provides some empirical evidence that better performance will be achieved by the market-oriented organization.
\end{abstract}

Key Words: Market Orientation; Firm Performance; China; United States

\section{INTRODUCTION}

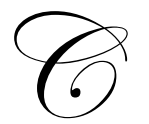

hina enjoys one of the strongest economies in Asia and ranks high in terms of overall global competitiveness. Over the last 20 years, China has seen major improvements in its GNI, prospered from over 260\% growth in its GDP, maintained a positive trade surplus, and enjoyed declining unemployment and inflation rates in comparison to other Asian countries. One of the drivers of this prosperity is its return to a free market economy.

One of the hallmarks of a successful free market economy is the market orientation of local industries (Jaworski and Kohli, 1993; Kohli, Jaworski, 1990, Day 1990, Narver and Slater 1990). In the past several decades, there has been a renewed academic and practitioner interest in the market orientation construct. This situation is logical since it stems directly from the marketing concept, which forms the foundation of effective marketing practice. The marketing concept has been described as a marketing management philosophy which guides what is thought to be best practice. However, a market orientation takes time to develop and environmental factors such as competitive intensity, governmental regulations and other external uncertainties can moderate the level of market orientation.

Very little market orientation research has been focused on Asia and even less on China. One study (Qu and Ennew. 2003) examined the early effects of market orientation and the moderating role of the environment. A second study focused on China's transitional economy but did not offer benchmarks for comparison (Qu and Ennew. 2005). Instead, it provided valuable insight into the effect of government and ownership on market orientation. No other published market orientation research to date has focused on China's growing economy. In order to understand the nature and scope of market orientation in China, the paper compares the current levels of market orientation in China to the United States, and discusses marketing implications. 


\section{BACKGROUND LITERATURE AND RESEARCH HYPOTHESES}

A decade ago, one criticism leveled at the market orientation construct was that despite its acknowledged importance, market orientation did not have a clear meaning or "a rich tradition of theory development, and a related body of empirical findings" (Kohli and Jaworski, 1990). There were numerous definitions and little empirically based theory. Moreover, there was little concern for the environmental factors that affect the proper orientation for a particular business. Over time, the construct has enjoyed continued refinement.

One of those refinements has focused on developing valid measures of market orientation. The first of the measures, attributed to Narver and Slater (1990), is one of the most comprehensive and has several positive features. For example, it adopts a focused view of markets by emphasizing customers and competitors as well as other environmental elements such as technology and regulation. While it is firmly grounded in the marketing concept, it tends to concentrate on external factors. In contrast, work by Kohli, Jaworski, and Kumar (1993) recognizes the activities in which firms engage to succeed. These involve the speed with which market intelligence is generated and disseminated within an organization, and which activities firms use to exploit that intelligence. This use of intelligence is typified by a firm's level of responsiveness. Kohli, Jaworski, and Kumar (1993) designed the market orientation measure (MARKOR). It assesses the degree to which an SBU (1) engages in multi-department market intelligence generation activities, (2) disseminates this intelligence vertically and horizontally through both formal and informal channels, and (3) develops and implements marketing programs on the basis of the intelligence generated.

Together, both approaches seem to capture the essence of market orientation. Underscoring the importance of both approaches to the construct, market orientation has been defined as a business culture that has two major elements. First, it places the highest priority on the profitable creation and maintenance of superior value for customers while considering the interest of other stakeholders. Second, it provides directions regarding the organizational generation and dissemination of and responsiveness to market information (Langerak, 2003). The concept of market orientation has an inherent logic that is well recognized. Moreover, the literature indicates that a company's market orientation is directly related to organizational performance (Langerak, 2003). Using either construct view, it appears that firms with a higher marketing orientation perform better than those with a lower marketing orientation. The measures of performance comprise metrics like profitability, sales growth, customer satisfaction, and successful introduction of new products. The underlying explanation may be that a market-oriented organizational culture produces a sustainable competitive advantage, and thus, superior long-run organizational performance (Hunt and Morgan, 1995).

The current research attempts to find answers to several questions. None have been researched in a Chinese context. The four research questions are:

1. What is the level of market orientation of Chinese firms?

2. Is there a difference between market orientation and external focus?

3. What is the link, if any, between market orientation and business performance?

4. Does degree of market orientation vary by type and size of organization?

5. Does managerial level moderate respondent perceptions of market orientation?

The research questions lead directly to the study's hypotheses.

\section{Business Performance}

Although marketing academics and practitioners have debated for more than three decades that business performance is affected by market orientation, the study by Narver and Slater (1990) was the first systematic empirical evidence of the effect of a market orientation on business profitability. Following Narver and Slater (1990), a number of studies, conducted mainly in the context of developed countries, have supported the positive relationship between market orientation and business performance (Ruekert 1992, Deshpande et al. 1993, Jaworksi and Kohli 1993, Slater and Narver 1994, Selnes et al. 1996, Pulendran et al. 2000). However, although the strength 
of the market orientation -performance relationship appears to be fairly strong, the robustness of the relationship across different environments is not clear. Several researchers have proposed that environmental factors might moderate the relationship (Han, Kim and Sristava 1998, Kumar, Subramanian \& Yauger 1998). In recent years, findings from developing economies have been more mixed (Bhuian 1998, Ngai and Ellis 1998, Hooley et al. 2000, Subramanian and Gopalakrishna 2001, Liu et al. 2003). These mixed findings have led some researchers to question the simple transferability of findings from developed countries (Ngai and Ellis 1998). Due to the importance of China in Asia and its robust business environment, we expect to find a positive relationship between a firm's market orientation and its performance. Thus, we postulate the following hypothesis:

$\mathbf{H}_{\mathbf{1}}$ : The degree of market orientation is positively linked with business performance.

\section{External Orientation}

As mentioned previously, two distinct scales have emerged to measure market orientation. Kohli, Jaworksi and Kumar (1993) focus on the activities of the firm (i.e., intelligence generation, intelligence dissemination, and responsiveness) and advance the use of the MARKOR scale. Narver and Slater (1990) adopt an external focus of market orientation. External focus is measured by a customer and competitive orientation. This study seeks to assess the reliability between the two approaches and therefore postulates the following:

$\mathbf{H}_{2}$ : Externally oriented organizational cultures lead to higher levels of performance and internally oriented (bureaucratic and consensual) cultures lead to lower levels of performance.

\section{Organizational Scope}

One argument for differing levels of market orientation in an economy is the influence of multinational firms which succeed in the global marketplace by developing a market oriented business strategy. Multinationals operate in most countries and have developed keen environmental sensing capabilities and are adept at responding to local needs. While firms in domestic industries may emulate some of the multinational's marketing practice, it is expected that they will lag behind them. The least progressive marketing firms may be in industries whose horizon is limited to local markets with their traditions and concentrated focus. National firms usually possess a broader perspective, at least as broad as the national market. Broader perspectives should sensitize firms to the need to monitor their markets. This gives rise to the following hypothesis:

$\mathbf{H}_{3}$ : International firms have a higher degree of market orientation than do local, domestic firms.

\section{Industry Type}

Products and services vary on many dimensions, not just their tangibility. On the whole, products, since they are tangible, and communicate their want satisfying benefits more completely than services whose intangibility may make their benefits less apparent. While it may be argued that service firms are under a greater burden to learn what customers want and need, service development is inherently more difficult than product development. Many researchers have suggested that the inherent nature of service organizations requires a strong market orientation (Kara et al. 2005). The intangibility of services and the maturity of service offerings have made developing a marketing orientation essential for service firms to develop a sustainable competitive advantage (Czepiel 1990, Perrien and Ricard 1995). Thus, we postulate the following:

$\mathbf{H}_{4}$ : Market orientation is greater in service industries than in manufacturing industries. 


\section{Economic Sector}

Under the Communist Party, private ownership of the means of production was sharply curtailed. After the revolution, state owned and provincial owned businesses predominated. The situation led to economic stagnation but widespread employment. Together with government control of prices, the situation was stabilized. The business climate was, at best, unexciting and because of government control, bureaucratic. Typical bureaucratic organizations tend to stunt creativity and tend to look inward rather than outward. Government organizations tend to avoid risks and, if they value improvements, concentrate on improving efficiency. They tend not to have competitors and they may not value satisfying customers. When Deng Xiao Ping served as General Secretary of the Communist Party, he relaxed private ownership restrictions and declared, "To be rich is glorious." That statement started a flood of foreign investment and some privatization that transformed the Chinese economy. The changes have themselves been revolutionary. Instead of the slow evolutionary dynamics that are present in the West, China underwent dramatic and sudden changes. The process has been described as the Big Bang in reference to the sweeping changes in regulations, investment climate and wealth. One question that arises is how quickly China's managers could assimilate business practices common across the globe. One under researched area focuses on the nature and scope of market orientation implementation in China.

As China's political control of the economy shifts to allow more private ownership, there could be shifts in firms' market orientation. Private ownership is often more entrepreneurial and more attuned to the elements that spell success and thus, we should expect differences in market orientation. Our hypothesis is as follows:

$\mathbf{H}_{5}$ : Market orientation is greater in private industry than in government or quasi-government firms.

\section{Size Of Organization}

Organizational research identifies the differences inherent in firms of different sizes. Therefore, we also test for differences in company size. Although there have been several studies investigating the market orientation of small businesses (Pelham 1999, 1997), these studies have been limited to developed economies and have used small manufacturing firms. Thus, on the basis of previous research, we have some mixed expectations about the relationship. For example, we expect that larger companies tend to be higher on market orientation than smaller companies. The effect is often a resource based result. Usually, larger companies have more resources like human resources, a professional marketing staff and more access to market research, than smaller firms. In addition, they may have the necessary infrastructure like formalized marketing departments and corporate communication specialists to pursue a market orientation. On the other hand, smaller firms may be more entrepreneurial and despite having fewer resources they may be more active in pursuing opportunities. On balance, the resource argument seems the more powerful. Therefore we postulate the following:

$\mathbf{H}_{\mathbf{6}}$ : Large firms are more market oriented than small firms.

\section{Managerial Level}

Organizational research also identifies the differences among managers in a company. Organizational level is a determinant of job responsibilities, job focus and manager orientation. Lower level managers usually have responsibilities focused within the company. They may include monitoring internal processes or supervising employees working in the firm. One exception is the sales force manager whose duties involve supervising salespeople who deal with customers. Often their duties focus on increasing individual performance rather than that of the sales team. Thus the intelligence generation, dissemination activities may be limited. Moreover responsiveness may be outside of their responsibilities. In contrast, higher level managers are usually concerned with managing a large part of the company. Working with several departments or groups increases their need to coordinate. In many cases coordination takes the form of managing intelligence and responding to opportunities and threats. Therefore:

$\mathbf{H}_{7}$ : Higher-level managers perceive greater market orientation than do lower level managers. 


\section{METHODOLOGY}

The purpose of the study is to gain an understanding of the level of market orientation in Chinese firms and use a sample of U.S. managers as a comparative basis. Additionally, the study aims to verify the relationship between market orientation and firm performance in an Asian context. The study employed a survey, administered in person to practicing managers. A 48 item questionnaire plus some descriptive questions were used to obtain data.

Table 1: Sample Profile

\begin{tabular}{|c|c|c|c|}
\hline & China & U.S. & Differences \\
\hline $\begin{array}{c}\text { Position in Organization } \\
\text { Entry Level } \\
\text { Mid Level } \\
\text { Senior Level }\end{array}$ & $\begin{array}{c}23 \\
22 \\
6\end{array}$ & $\begin{array}{c}25 \\
4 \\
7\end{array}$ & $\begin{array}{c}\mathrm{F}=1.477 \\
\mathrm{p}=.228\end{array}$ \\
\hline $\begin{array}{c}\text { Years at Organization } \\
\text { 1-2 Years } \\
\text { 3-8 Years } \\
\text { 9-14 Years } \\
\text { 15-20 Years } \\
\text { 20+ Years }\end{array}$ & $\begin{array}{c}10 \\
36 \\
1 \\
2 \\
0\end{array}$ & $\begin{array}{c}21 \\
13 \\
2 \\
0 \\
0\end{array}$ & $\begin{array}{l}\mathrm{F}=.032 \\
\mathrm{p}=.859\end{array}$ \\
\hline $\begin{array}{l}\text { Ownership } \\
\text { Private sector } \\
\text { Public sector }\end{array}$ & $\begin{array}{c}45 \\
7 \\
\end{array}$ & $\begin{array}{l}16 \\
15\end{array}$ & $\begin{array}{c}\mathrm{F}=34.633 \\
\mathrm{p}=.000\end{array}$ \\
\hline $\begin{array}{c}\text { Scope of Operations } \\
\text { Domestic } \\
\text { International } \\
\text { Global }\end{array}$ & $\begin{array}{c}33 \\
11 \\
9\end{array}$ & $\begin{array}{c}11 \\
7 \\
18\end{array}$ & $\begin{array}{c}\mathrm{F}=2.480 \\
\mathrm{p}=.119\end{array}$ \\
\hline $\begin{array}{l}\text { Type of Organization } \\
\text { Manufacturing } \\
\text { Service }\end{array}$ & $\begin{array}{l}33 \\
19\end{array}$ & $\begin{array}{c}19 \\
7\end{array}$ & $\begin{array}{c}\mathrm{F}=3.312 \\
\mathrm{p}=.073\end{array}$ \\
\hline $\begin{array}{c}\text { Size of Organization } \\
\text { Small } \\
\text { Medium } \\
\text { Large }\end{array}$ & $\begin{array}{c}12 \\
8 \\
20\end{array}$ & $\begin{array}{l}18 \\
18 \\
30\end{array}$ & $\begin{array}{c}\mathrm{F}=.0003 \\
\mathrm{p}=.978\end{array}$ \\
\hline
\end{tabular}

\section{The Sample}

The first stage in the study was to select samples of Chinese and US managers. Two samples of managers enrolled in their second year of MBA programs in the respective countries were drawn. All respondents were fullyemployed in managerial position within their organizations. A total of 89 subjects were included, 51 worked in China while 37 worked in the US. Table 1 provides a general description of the two samples. The Chinese sample and US samples are not significantly different with the exception of private versus public sector and manufacturing versus service companies. The China sample had a lower proportion of manufacturing to service firms compared to the US sample. In addition, the China sample had a much higher proportion of executives employed in private versus public companies than did the US sample.

\section{Questionnaire Development}

The questionnaire was created in English to be administered to English speaking managers. The questionnaire was constructed using a combination of the MARKOR scale of Kohli, Jaworski, and Kumar (1993) and the external orientation scale of Narver and Slater (1990). The questionnaire included 29 items designed to assess the five different components of market and external orientation: customer orientation (items 1-6), competitor orientation (items 7-9), intelligence generation (items 10-15), intelligence dissemination (items 16-20), and responsiveness (items 20-29). Response to each item was measured on a seven point Likert scale ranging from 
'strongly disagree' (1) to 'strongly agree' (7). In addition descriptive measures and measures of perceived firm performance were taken. Questions used in the questionnaire can be found in Appendix A.

\section{Scale Validity And Reliability}

Factor analysis, using principal components analysis and Varimax rotation, confirmed scale development and yielded five different factors. Twenty five of the 29 items loaded on five factors explaining $64 \%$ of the total variance. The factors were labeled 'intelligence generation' (factor 1), 'competitor orientation' (factor 2), 'customer orientation' (factor 3), 'intelligence dissemination' (factor 4), and responsiveness (factor 5). The dimensions are consistent with both the Kohli and Jaworski (1990) and Narver and Slater (1990) frameworks.

To assess the reliability of the scales, Cronbach's Alpha was calculated for the overall measure of market orientation (MO), the overall measure of external orientation (EO), and each of their respective sub-scales. Scores for each of the three dimensions of market orientation (i.e., intelligence generation, intelligence dissemination, and responsiveness) were combined to yield a measure of market orientation. Scores for customer orientation and competitor orientation were combined to yield a measure of external orientation. The results of the analysis for each sample as well as for the combined sample are provided in Table 2. The Alpha scores for both the MO scale and EO scale were well above the benchmark level of 0.70 suggested by Nunnally (1994) and thus judged to have sufficient reliability.

Table 2: Construct Reliability and Scores

\begin{tabular}{|c|c|c|c|}
\hline $\begin{array}{c}\text { Scale Item } \\
\text { Cronbach's Alpha) }\end{array}$ & Overall Sample & China Sample & U.S. Sample \\
\hline Market Orientation & $\mathbf{. 9 0 8}$ & $\mathbf{. 8 9 6}$ & $\mathbf{. 9 1 9}$ \\
\hline External Orientation & $\mathbf{. 8 7 7}$ & $\mathbf{8 6 7}$ & .886 \\
\hline Customer Orientation & .887 & .901 & .837 \\
\hline Competitor Orientation & .793 & .719 & .741 \\
\hline Intelligence Generation & .766 & .798 & .846 \\
\hline Intelligence Dissemination & .732 & .754 & .883 \\
\hline Responsiveness & .865 & .845 & \\
\hline
\end{tabular}

\section{DATA ANALYSIS}

Data analysis was structured around the five research questions: level of market orientation, market orientation affect on business performance, differentiation between marketing orientation and external orientation, the variability of market orientation across size and type of firm, and the affect of managerial level of perceptions of market orientation. The six hypotheses are embedded within these five areas.

\section{Level Of Market Orientation}

The first step in data analysis was to compare and contrast the level of market orientation. Table 3 compares the means of market and external orientation, and their respective subscales, between the Chinese and United States samples. Some of the subscales of the two samples show statistically significant differences. On the market orientation dimension, intelligence generation and intelligence dissemination scores are similar but the responsiveness scores are significantly different. The China sample shows a lower mean score than the US sample and indicates that US managers rate their companies' responsiveness higher.

The external orientation measure showed two significant differences between the samples. The overall measure of external orientation $(\mathrm{p}=.046)$ and one of its components, competitor orientation $(\mathrm{p}=.028)$ are significantly different. In both cases the China sample showed a higher mean than the US sample. Chinese managers rate their companies as more competitor oriented, and thus more externally oriented than their US counterparts. The larger proportion of private sector employees in the China sample may account for the differences in competitor orientation since public sector organizations often ignore or have no competitors. 
Table 3: Comparison of Market Orientation

\begin{tabular}{|c|c|c|c|}
\hline Scale & China Sample & U.S. Sample & Significance China vs US \\
\hline Market Orientation (Overall) & 4.54 & 4.44 & $\mathrm{~F}=2.72, \mathrm{p}=.103$ \\
\hline Intelligence Generation & 4.79 & 4.45 & $\mathrm{~F}=.808, \mathrm{p}=.371$ \\
\hline Intelligence Dissemination & 4.75 & 4.63 & $\mathrm{~F}=1.135, \mathrm{p}=.290$ \\
\hline Responsiveness & 4.08 & 4.26 & $\mathrm{~F}=5.879, \mathrm{p}=.017$ \\
\hline External Orientation (Overall) & 5.19 & 4.98 & $\mathrm{~F}=4.114, \mathrm{p}=.046$ \\
\hline Customer Orientation & 5.17 & 5.16 & $\mathrm{~F}=.028, \mathrm{p}=.867$ \\
\hline Competitor Orientation & 5.22 & 4.80 & $\mathrm{~F}=10.557, \mathrm{p}=.002$ \\
\hline
\end{tabular}

\section{Market Orientation And Business Performance}

The second research question focused on the link between market orientation and business performance. The questionnaire contained nine separate items that assessed the respondent's perception of his or her firm's performance. The first two items (overall performance of my company for the past 12 months and overall performance relative to major competitors) assessed overall performance. The last seven items (market share growth; sales volume; profitability; achieving customer satisfaction retaining current customers; attracting new customers; and building a positive image) assessed individual performance criteria relative to major competitors. Response to each item was measured on a seven point Likert scale ranging from 'far below competitors' (1) to 'far above competitors' (7). Similarly, the overall scores and the seven criteria were averaged to yield a second performance measure. Table 4 provides a comparison of business performance across the two samples. Results show that only one of the items, customer retention, was significantly different across the samples.

Respondents in the Chinese sample indicated slightly lower levels of customer retention with a mean response of 4.78 , compared to their US counterparts with a mean of 4.86 .

Table 4: Comparison of Business Performance

\begin{tabular}{|c|c|c|c|}
\hline Scale Item & China Sample & U.S. Sample & Significance China vs US \\
\hline Overall Business Performance & 5.08 & 5.41 & $\mathrm{~F}=.619, \mathrm{p}=.433$ \\
\hline Individual Business Performance & 5.06 & 5.35 & $\mathrm{~F}=.002, \mathrm{p}=.964$ \\
\hline Market Share Growth & 4.51 & 4.83 & $\mathrm{~F}=.217, \mathrm{p}=.642$ \\
\hline Sales Volume & 4.57 & 4.58 & $\mathrm{~F}=.072, \mathrm{p}=.789$ \\
\hline Profitability & 4.65 & 4.77 & $\mathrm{~F}=.482, \mathrm{p}=.490$ \\
\hline Customer Satisfaction & 4.92 & 4.89 & $\mathrm{~F}=.134, \mathrm{p}=.715$ \\
\hline Customer Retention & 4.78 & 4.86 & $\mathrm{~F}=5.144, \mathrm{p}=.026$ \\
\hline Customer Acquisition & 4.75 & 4.89 & $\mathrm{~F}=.154, \mathrm{p}=.696$ \\
\hline Market Image & 5.15 & 5.14 & $\mathrm{~F}=.828, \mathrm{p}=.365$ \\
\hline
\end{tabular}

Otherwise, the two country samples are judged to be similar in terms of responses to the business performance questions. The effect might be due to increasing interest in customer retention in US business. Companies have recognized the lower cost and higher return in serving existing customers compared to finding new ones. Perhaps the situation in China is more focused on startup and success than in the US.

The first hypothesis postulates that the degree of market orientation is positively linked with business performance. To test the hypothesis, we conducted separate regression analyses using the different measures of business performance as the dependent variables, with market orientation and its subscales as the predicting variables. The results are reported in Table 5. In the US sample, the relationship between market orientation and business performance is significant across all components of performance. The market orientation - performance relationship is almost as consistent and significant in the Chinese sample. Market orientation drives overall business performance, profitability, customer satisfaction, retention and acquisition. In both samples it was not found to be significant in driving market share growth. In the China sample alone, it was not significantly related to market share growth. The results provide mixed but strong support for $\mathrm{H}_{1}$. 
Table 5: Effect of Market Orientation on Business Performance

\begin{tabular}{|c|c|c|}
\hline \multicolumn{2}{|c|}{ Independent Variable - Market Orientation } \\
\hline Dependent Variables & China Sample & US Sample \\
\hline Overall Performance & $\mathrm{F}=16.84, \mathrm{p}=.000$ & $\mathrm{~F}=34.33, \mathrm{p}=.000$ \\
\hline Market share Growth & $\mathrm{F}=2.57, \mathrm{p}=.115$ & $\mathrm{~F}=4.79, \mathrm{p}=.036$ \\
\hline Sales Volume & $\mathrm{F}=2.35, \mathrm{p}=.132$ & $\mathrm{~F}=1.47, \mathrm{p}=.234$ \\
\hline Profit & $\mathrm{F}=4.53, \mathrm{p}=.038$ & $\mathrm{~F}=14.33, \mathrm{p}=.014$ \\
\hline Customer Satisfaction & $\mathrm{F}=33.69, \mathrm{p}=.000$ & $\mathrm{~F}=8.29, \mathrm{p}=.007$ \\
\hline Customer Retention & $\mathrm{F}=8.98, \mathrm{p}=.004$ & $\mathrm{~F}=10.27, \mathrm{p}=.003$ \\
\hline Customer Acquisition & $\mathrm{F}=3.95, \mathrm{p}=.052$ & $\mathrm{~F}=11.29, \mathrm{p}=.002$ \\
\hline
\end{tabular}

\section{External Orientation As A Driver Of Business Performance}

The second hypothesis postulated that externally oriented organizational cultures lead to higher levels of performance and internally oriented (bureaucratic and consensual) cultures lead to lower levels of performance. To test this hypothesis, performance and each of its components was entered as the dependent variable and the external orientation measure was entered as the independent variable. Separate regressions were run for each measure of performance. The results are shown in Table 6. In the both samples, the relationship between external orientation and business performance is significant across all components of performance. The results provide strong support for $\mathrm{H}_{2}$.

Table 6: Effect of External Orientation on Business Performance

\begin{tabular}{|c|c|c|}
\hline \multicolumn{2}{|c|}{ Independent Variable - External Orientation } \\
\hline Dependent Variables & China Sample & US Sample \\
\hline Overall Performance & $\mathrm{F}=28.46, \mathrm{p}=.000$ & $\mathrm{~F}=17.79, \mathrm{p}=.000$ \\
\hline Market share Growth & $\mathrm{F}=8.11, \mathrm{p}=.006$ & $\mathrm{~F}=5.02, \mathrm{p}=.032$ \\
\hline Sales Volume & $\mathrm{F}=4.00, \mathrm{p}=.051$ & $\mathrm{~F}=5.07, \mathrm{p}=.094$ \\
\hline Profit & $\mathrm{F}=9.75, \mathrm{p}=.031$ \\
\hline Customer Satisfaction & $\mathrm{F}=29.07, \mathrm{p}=.000$ & $\mathrm{~F}=19.56, \mathrm{p}=.000$ \\
\hline Customer Retention & $\mathrm{F}=16.05, \mathrm{p}=.000$ & $\mathrm{~F}=13.37, \mathrm{p}=.001$ \\
\hline Customer Acquisition & $\mathrm{F}=6.36, \mathrm{p}=.015$ & $\mathrm{~F}=16.95, \mathrm{p}=.000$ \\
\hline Image & $\mathrm{F}=9.64, \mathrm{p}=.003$ & $\mathrm{~F}=17.27, \mathrm{p}=.000$ \\
\hline
\end{tabular}

\section{Variability Of Market Orientation By Firm Type And Size}

The third major area of research inquiry was the degree to which market orientation varies by the type and size of the organization. Specifically, our third hypothesis postulates that international firms have a higher degree of market orientation than do local, domestic firms. To test this hypothesis, we conducted a regression analysis using market orientation as the dependent variable, and firm scope (global, international or domestic) as the predicting dummy variable. The results for both the China and US samples are provided in Table 7. The results are mixed. The China sample does not show a significant relationship between market orientation and organizational scope; the US relationship is significant. Thus, there is mixed support for $\mathrm{H}_{3}$. Although both samples are not significantly different in terms of organizational scope, the US sample does have a higher proportion of global firms represented. Alternatively, the differences may lie in the level of organizational maturity. US firms have been exposed to market orientation concepts for a long time. In addition, they are active in striving to compete globally and may face greater pressure to attend to the market. That factor, maturity, may account for some of the differences. 
Table 7: Summary of Regression Findings

\begin{tabular}{|c|c|c|c|}
\hline Independent Variable & Dependent Variable & China Sample & US Sample \\
\hline $\mathrm{H}_{3}:$ Organizational scope & Market orientation & $\mathrm{F}=1.23, \mathrm{p}=.274$ & $\mathrm{~F}=6.43, \mathrm{p}=.016$ \\
\hline $\begin{array}{c}\mathrm{H}_{4}: \text { Industry type } \\
\text { (service vs mfg) }\end{array}$ & Market orientation & $\mathrm{F}=.015, \mathrm{p}=.748$ & $\mathrm{~F}=4.98, \mathrm{p}=.033$ \\
\hline $\begin{array}{c}\mathrm{H}_{5}: \text { Economic sector } \\
\text { private vs government) }\end{array}$ & Market orientation & $\mathrm{F}=6.99, \mathrm{p}=.011$ & $\mathrm{~F}=.049, \mathrm{p}=.826$ \\
\hline $\mathrm{H}_{6}:$ Organization size & Market orientation & & $\mathrm{F}=.164, \mathrm{p}=.688$ \\
\hline $\mathrm{H}_{7}:$ Managerial level & Market orientation & $\mathrm{F}=.508, \mathrm{p}=.479$ & \\
\hline
\end{tabular}

The fourth hypothesis is concerned with the relationship between market orientation and the service versus manufacturing classification of the firm. The hypothesis states: $\mathrm{H}_{4}$ : Market orientation is greater in service industries than in manufacturing industries. To test this hypothesis, individual responses to the specific industry question (question 10) were recoded to reflect the nature of the industry. Thus, manufacturing was clearly a manufacturing industry and transportation was coded as a service industry. A regression analysis was performed with market orientation as the dependent variable and industry type entered as a dummy independent variable. The results, shown in Table 7, are not statistically significant for either the US sample or the China sample. Thus, this hypothesis is not supported.

The fifth hypothesis attempts to assess the relationship of government or private ownership on market orientation. The hypothesis states: $\mathrm{H}_{5}$ : Market orientation is greater in private industry than in the government/public sector. The instrument question dealing with the ownership of the subject's organization used eight response categories. Each category was assessed and categorized as mainly in either the government or private sector. Each response was recoded into government or private and used as dummy variables in a regression analysis. Marketing orientation was the dependent variable. The regression results are shown in Table 7. Significant results are shown for both samples. The results support the hypothesis.

The sixth hypothesis concerns the relationship between firm size and the organization's level of market orientation. It states that $\mathrm{H}_{6}$ : Large firms are more market oriented than small firms. The questionnaire contained a question about the size of the respondent's organization. That data was recoded into three categories, small, medium and large. In order to use the data as dummy variables, a second category was created to accommodate the third value, large. To test this hypothesis market orientation was entered as the dependent variable and each of the two size dummy variables entered as independent variables. The results for the US sample, show in Table 7, are not statistically significant and the hypothesis is not supported. The seventh and last hypothesis deals with managers and their level in their organizations. It states: $\mathrm{H}_{7}$ : Higher-level managers perceive greater market orientation than do lower level managers. The question offered ten different response levels ranging from entry level to top level manager. Once again market orientation was entered as a dependent variable. Managerial level was entered as the dependent variable. The results, shown in Table 7, are not significant and the hypothesis is not supported.

\section{DISCUSSION AND IMPLICATIONS}

The results of this study demonstrate that market orientation is a valid construct. Both the Kohli and Jaworski MARKOR scale and Narver and Slater's external orientation scale produced similar results. Each scale was deemed to be a reliable measure of market orientation in Chinese firms and lends credence to the universal applicability of market orientation in the Latin American setting.

Given China's overall global competitiveness and its robust economy, it is not surprising that levels of market orientation did not differ significantly between the US and Chinese samples. The overall level of market orientation in China is strong, whether measured by the MARKOR MO scale or the EO scale. Chinese firms also scored high on overall business performance, though slightly less than their US counterparts. Furthermore, a Chinese firm's overall business performance was found to be significantly related to its market orientation, 
especially in regards to markets and customer satisfaction. These finding are supported in the literature and were expected.

The present study also yields several insights regarding the specific hypotheses related to the variability of market orientation by firm type and size. As expected, the level of market orientation is greater in the private sector than in the public/government sector. The profit motive in private industry is a strong driver of business success and hence, market orientation. Interestingly, market orientation is also greater for service-driven companies than for manufacturing firms. Market orientation did not differ significantly whether the firm was primarily a domestic player or international in its scope of operations.

An important finding pertains to the measurement of the two constructs of market orientation. Most researchers have conceptualized this construct as being multidimensional. However, researchers have not always agreed on exactly what the dimensions share. One piece of evidence confirming this controversy is the difference in the dimensions of market orientation developed by Kohli and Jaworski (1990) and Narver and Slater (1990). The dimensions for market orientation that we found in this study suggest that market orientation include aspects of each.

\section{Limitations}

While interpreting the significant of the results, it is important to keep in mind some of the limitations of this study. The sample size is a limiting factor in the study. The Chinese sample represented only 61 Chinese managers and thus limits the extent to which the findings can be generalized to the Chinese market. Second, it would be beneficial use both objective and subjective measures of performance. Unfortunately, while objective measures of financial performance can be obtained in some cases, it may not be possible to obtain objective measures of other performance dimensions, such as customer satisfaction, market share growth, quality assessment.

\section{CONCLUSION}

Notwithstanding these limitations, we believe that these preliminary findings provide important insights into Chinese business practices. This analysis shows that Chinese firms have a strong market orientation. They recognize the importance of being kept informed about environmental trends, competitor activities and the evolving needs of their customers. They disseminate information among their staff and respond to opportunities to provide better products and quality services to their customers. Although the relationship between market orientation and business performance may be complex, this study provides some empirical evidence that better performance will be

achieved by the market-oriented organization. Market orientation may be one explanation why China is a strong global competitor.

\section{REFERENCES}

1. Bhuian, S.N. (1998), An Empirical Examination of Market Orientation in Saudi Arabia Manufacturing Companies, Journal of Business Research, 43, 13-25.

2. Czepiel, J. A. (1990), Managing Relationships with Customers: A Differentiating Philosophy of Marketing, Service Management Effectiveness: Balancing Strategy, Human Resources, Operations and Marketing, D.E. Brown, R. B. Chase and T. G. Cummings, eds. San Francisco: Jossey-Bass.

3. Dawes. J. (1999), The Relationship between Subjective and Objective Performance Measure in Market Orientation Research: Further Empirical Evidence, Marketing Bulletin, 10, 65-75.

4. $\quad$ Day, G. (1990), Market-Driven Strategy. New York: The Free Press.

5. Deshpande, R., J.U. Farley and F.E. Webster (1993), Corporate Culture, Customer Orientation, and Innovativeness in Japanese Firms: A Quadrad Analysis, Journal of Marketing, 57 (1), 23-37.

6. Gronroos, C. (1991), The Marketing Strategy Continuum: Toward a Marketing Concept. Services Marketing Management Decision, 29 (1), 17-13.

7. Han, J.K., N. Kim and R. Srivastava (1998), Marketing Orientation and Organizational Performance: Is Innovation a Missing Link, Journal of Marketing, 62 (October), 81-87. 
8. Hooley, G.J., J. Fahy, G. Greenley, J. Beracs, K. Fonfara and B. Snoj (2003), Market Orientation in the Service Sector of the Transition Economies of Central Europe, European Journal of Marketing, 37 (1/2) 86106

9. Hunt, S. and R. M. Morgan (1995), The Comparative Advantage Theory of Competition, Journal of Marketing, 59 (2), 1-15.

10. Jaworski, B.J. and A.K. Kohli, (1993) Market Orientation: Antecedents and Consequences, Journal of Marketing, 57 (July), 53-7.

11. Kara, A., J.E. Spillan and O.W. DeShields (2005), The Effect of a Market Orientation on Business Performance: A Study of Small-Sized Service Retailers Using MARKOR Scale, Journal of Small Business Management, 42 (2), 105-118.

12. Kohli, A.K. and B.J. Jaworski (1990), Market Orientation: The Construct, Research Propositions, and Managerial Implications, Journal of Marketing, 54 (April), 18.

13. Kohli, A.K., B.J. Jaworski, and A. Kumar (1993). Journal of Marketing Research, 30 (November), $467-$ 77.

14. Kumar, K., R. Subramanian and C. Yauger (1998), Examining the Market Orientation-Performance Relationship: a Context Specific Study, Journal of Management, 24 (2), 201-233.

15. Langerak (2003), The Effect of Market Orientation on Positional Advantage and Organizational Performance, Journal of Strategic Marketing, 11 (June), 93-115.

16. Liu, S.S. X. Luo and Y-Z Shi (2003), Market-Oriented Organizations in an Emerging Economy: A Study of Missing Links, Journal of Business Research, 56 (6), 481-92.

17. Narver, J.C. and Slater, S.F. (1990), The Effect of Market Orientation on Business Profitability. Journal of Marketing, 54 (October), 20-35.

18. Narver, J.C. and Slater, S.F. (1998) Additional Thoughts on the Measurement of Market Orientation. Journal of Market Focused Management, 2(1), 233-6.

19. Ngai, C. H. and P. Ellis (1998), Market Orientation and Business Performance: Some Evidence from Hong Kong, International Marketing Review, 15 (2).

20. Nunnally, J.C. (1994), Psychometric Theory, $3^{\text {rd }}$ edition, New York: McGraw-Hill.

21. Pelham, A. (1997), Mediating Influences on the Relationship between Market Orientation and Profitability in Small Industrial Firm, Journal of Marketing Theory and Practice, 5 (2), 1-23.

22. Pelham, A. (1999), Influence of Environment, Strategy, and Market Orientation on Performance in Small Manufacturing Firms, Journal of Business Research, 45, 33-46.

23. Perrien, J.P. and L. Ricard (1995), The Meaning of a Marketing Relationship: A Pilot Study, Industrial Marketing Management, 24 (1), 37-43.

24. Pulendran, S., R. Speed and R.E. Widing (2000), The Antecedents and Consequences of Market Orientation in Australia, Australian Journal of Management, 25 ( 2), 119-44.

25. Qu, Riliang, Ennew, Christine T. (2005) Developing a Market Orientation in a Transitional Economy: The Role of Government Regulation and Ownership Structure. Journal of Public Policy \& Marketing, Spring, Vol. 24, Issue 1.

26. Ruekert, R.W. (1992), Developing a Market Orientation: An Organizational Strategic Perspective, International Journal of Research in Marketing, 9, 225-54.

27. Selnes, F., B.J. Jawoerksi and A.K. Kohli (1996), Market Orientation in United States and Scandinavian Companies: A Cross-Cultural Study, Scandinavian Journal of Management, 12 (2).

28. Slater, S.F. and J.C. Narver (1994), Does Competitive Environment Moderate the Market OrientationPerformance Relationship? Journal of Marketing, 58, (January), 46-55.

29. Slater, S.F. and Narver, J.C. (2000) The positive effect of a market orientation on business profitability: a balanced replication. Journal of Business Research, 48(1), 69-73.

30. Subramanian, R. and P. Gopalakrishna (2001), The Market Orientation-Performance Relationship in the Context of a Developing Economy, Journal of Business Research, 53, (1). 


\section{APPENDIX}

\begin{tabular}{rrrrrrr} 
& \multicolumn{3}{c}{ Market Orientation Questions } & & Strongly Agree \\
\hline Strongly Disagree & 2 & 3 & 4 & 5 & 6 & 7
\end{tabular}

Customer orientation (1-6)

1. We constantly monitor our level of commitment and orientation to serving our customers.

2. Our business objectives are driven primarily by customer satisfaction.

3. Our strategy for competitive advantage is based on our understanding of customer needs.

4. Our business strategies are driven by our beliefs about how we can create greater value for our customers.

5. We measure customer satisfaction systematically and frequently.

6. We give close attention to after-sales service.

\section{Competitor orientation (7-9)}

$7 . \quad$ We rapidly respond to competitive actions that threaten us.

8. Our salespeople regularly share information within our organization concerning competitors' strengths and weaknesses.

9. We target customers where we have a competitive advantage.

\section{$\underline{\text { Intelligence Generation (10-15) }}$}

10. We meet with customers at least once a year to find out what products or services they will need in the future.

11. We do a lot of in-house market research.

12. We are slow to detect changes in our customers' product preferences.

13. We poll end users at least once a year to assess the quality of our products and services.

14. We are slow to detect fundamental shifts in our industry (for example, competition, technology, regulation).

15. We periodically review the likely effects of changes in our business environment (for example, regulation) on customers.

Intelligence Dissemination (16-20)

16. We have interdepartmental meetings at least once a quarter to discuss marketing trends and developments.

17. Marketing personnel in our business unit spend time discussing customers' future needs with other functional departments.

18. When something important happens to a major customer or market, the whole business unit knows about it within a short period.

19. Data on customer satisfaction are shared at all levels in this business unit on a regular basis.

20. When one department finds out something important about competitors, it is slow to alert other departments.

\section{$\underline{\text { Responsiveness (21-29) }}$}

21. It takes us a long time to decide how to respond to our competitor's price changes.

22. For one reason or another, we tend to ignore changes in our customers' product or service needs.

23. We periodically review our product development efforts to ensure that they are in line with what customers want.

24. Several departments get together periodically to plan a response to changes taking place in our business environment.

25. If a major competitor were to launch an intensive campaign targeted at our customers, we would implement a response immediately.

26. The activities of the different departments in this business unit are well coordinated.

27. Customer complaints fall on deaf ears in this business unit. 
28. Even if we came up with a great marketing plan, we probably would not be able to implement it in a timely fashion.

29. When we find that customers would like to modify a product or service, the departments involved make tremendous efforts to do so.

Business Orientation Questions

Instructions: Please circle the number that best represents your opinion regarding the overall performance of your organization.

Poor

1

34

5

Excellent

1. The overall performance of my company for the past 12 months was:

2. Overall performance of our firm for the past 12 months relative to major competitors was:

\begin{tabular}{|c|c|c|c|c|}
\hline $\begin{array}{c}\text { Far } \\
\text { Below } \\
\text { Competitors }\end{array}$ & $\begin{array}{l}\text { Slightly } \\
\text { Below }\end{array}$ & Same & $\begin{array}{l}\text { Slightly } \\
\text { Above }\end{array}$ & $\begin{array}{c}\text { Far } \\
\text { Above } \\
\text { Competitors }\end{array}$ \\
\hline 1 & 3 & 4 & 5 & 7 \\
\hline
\end{tabular}

1. My firm's market share growth in our primary market for the past 12 months relative to major competitors.

2. My firm's sales volume generated over the past 12 months relative to major competitors.

3. My firm's profitability relative to major competitors over the past 12 months.

4. My firm's success in achieving customer satisfaction over the past 12 months relative to major competitors.

5. My firm's success in retaining current customers relative to major competitor's during the past as months.

6. My firm's success in attracting new customers during the past 12 months relative to major competitors.

7. My firm's success in building a positive image relative to major competitors over the past 12 month.

\section{NOTES}




\section{NOTES}

